\title{
Gibberellin promotion of physiological leaf spot in detached 'Golden Delicious' apple leaves*
}

\author{
W. J. Kender ${ }^{1}$ and H. Jonkers
}

Department of Horticulture, Agricultural University, Wageningen, the Netherlands Accepted: 3 January 1975

\section{Summary}

Physiological leaf spot development in detached 'Golden Delicious' apple leaves was accelerated when cultured in solutions containing $\mathrm{GA}_{3}$ or $\mathrm{GA}_{4+7}$ at 10,50 and $100 \mathrm{mg} /$ litre for $72 \mathrm{~h}$. The interaction of PBA and $\mathrm{GA}_{4+7}$ applied simultaneously was highly synergistic in increasing the severity of the disorder over either growth substance alone.

\section{Introduction}

Leaf spot, a non-pathogenic disorder specific to the apple cv. 'Golden Delicious', may appear on mature leaves in the orchard usually in July and August (Jonkers, 1973a). The incidence of the large irregular necrotic spots generally results in premature abscission of the affected leaves. Environmental conditions which tend to provoke the disorder are low light intensity, specific temperature regimes, and vigorous shoot growth (Jonkers, 1973b). Leaf spot severity is also governed by season. The physiology of leaf spot is unclear although we have shown that exogenous $\mathrm{GA}_{4+7}$ accelerates leaf spot and ABA retards it in intact trees (Kender \& Jonkers, 1975).

To understand more of the hormonal implications of leaf spot development these experiments were conducted to study the effects of specific growth substances on detached 'Golden Delicious' apple leaves.

\section{Material and methods}

Fully expanded leaves on terminal shoots were collected from 6-year old fruiting 'Golden Delicious' apple trees on M.9 rootstocks during July, 1974. Average leaf area was $66.3 \mathrm{~cm}^{2}$. Approximately $15 \%$ of the foliage exhibited leaf spot during

* Publication 421, Laboratorium voor Tuinbouwplantenteelt, Landbouwhogeschool, Wageningen, the Netherlands.

1 Visiting Scientist on leave from the Department of Pomology and Viticulture, New York State Agricultural Experiment Station, Cornell University, Geneva, N. Y., USA. 
this period. Leaves (with petioles) were detached from nodes 12 to 16 shoots $40-60$ $\mathrm{cm}$ in length and brought immediately to the laboratory for treatment. Ten replicate petioles were placed in $200-\mathrm{ml}$ beakers filled with solutions containing the respective growth substances. The petioles were inserted through an aluminium foil cover over each beaker to prevent the blades from contacting the solution. Leaves were maintained at $21{ }^{\circ} \mathrm{C}$ under continuous light $\left(33.6 \mathrm{~W} / \mathrm{m}^{2}\right)$ as suggested from previous data on intact trees (Jonkers, 1973a). Solutions were replaced daily.

Experiment 1. Leaves were cultured in solutions containing either 6-(benzylamino)9-(2-tetrahydropyranyl) 9H-purine (PBA), a mixture of gibberellins 4 and 7 $\left(\mathrm{GA}_{4+7}\right)$, gibberellic acid $\left(\mathrm{GA}_{3}\right)$ or abscisic acid (ABA) at 10,50 and $100 \mathrm{mg} / \mathrm{litre}$, indoleacetic acid (IAA) at 1,10 and $25 \mathrm{mg} /$ litre, or water. The experiment was replicated 2 times, first with unspotted leaves and second with leaves exhibiting one spot per leaf prior to detachment. The number and area of new spots were recorded on the same leaves after 24,48 and $72 \mathrm{~h}$.

Experiment 2. Detached unspotted leaves, as described above, were cultured in solutions containing either PBA at $0,1,10$ and $100 \mathrm{mg} / 1, \mathrm{GA}_{4+7}$ at $0,1,10$ and
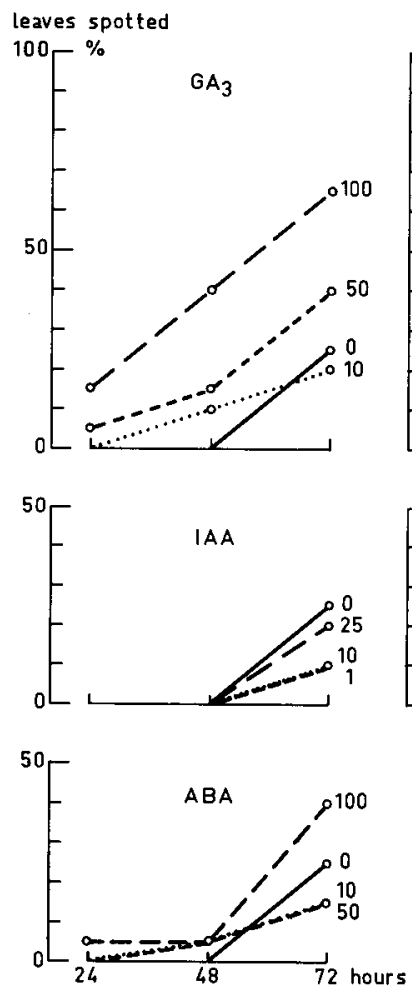
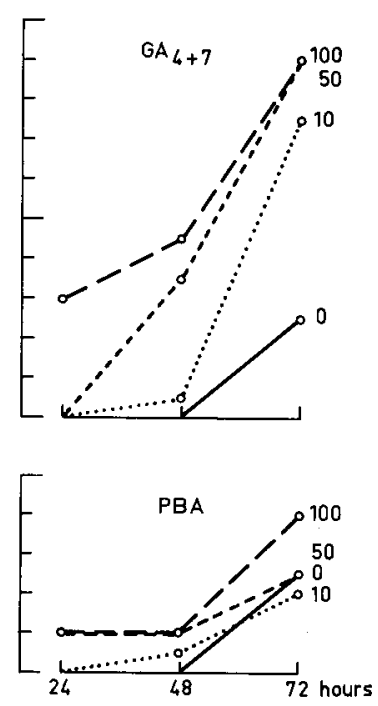

Fig. 1. The effect of $\mathrm{GA}_{3}, \mathrm{GA}_{4+7}$, IAA, PBA and ABA at various concentrations on the percentage of detached 'Golden Delicious' apple leaves developing leaf spots after 24,48 , and $72 \mathrm{~h}$. 


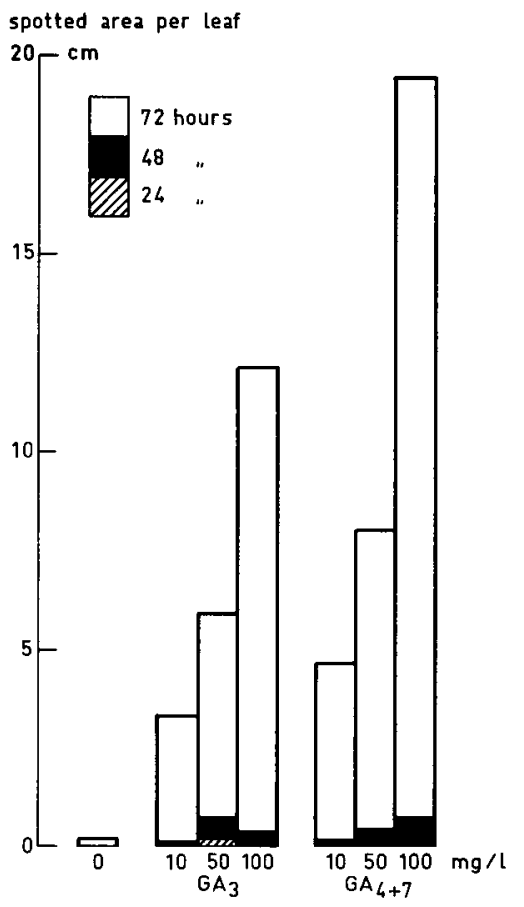

Fig. 2. The effect of $\mathrm{GA}_{3}$ and $\mathrm{GA}_{4+7}$ at 10,50 , and $100 \mathrm{mg} /$ litre on the total spotted area per leaf of detached 'Golden Delicious' apple leaves after 24. 48 and $72 \mathrm{~h}$.

$100 \mathrm{mg} / \mathrm{l}$, or all combinations of concentrations of the 2 growth substances (Table 1). The number and area of spots per leaf were recorded after $72 \mathrm{~h}$.

\section{Results}

Experiment 1. After $24 \mathrm{~h}$ the percentage of leaf spot on detached 'Golden Delicious' apple leaves was minimal in all growth regulator treatments, except $\mathrm{GA}_{4+7}$ at $100 \mathrm{mg} /$ litre which exhibited $30 \%$ leaf spot within $24 \mathrm{~h}$ (Fig. 1). After $48 \mathrm{~h}$, $\mathrm{GA}_{4+7}$ at 50 and $100 \mathrm{mg} /$ litre and $\mathrm{GA}_{3}$ at $100 \mathrm{mg} /$ litre increased the percentage of leaves which developed leaf spots. After $72 \mathrm{~h}, \mathrm{GA}_{4+7}$ at all concentrations and $\mathrm{GA}_{3}$ at $100 \mathrm{mg} /$ litre markedly stimulated the number of leaves with spots. The other growth substance had little effect on the percentage leaves showing spots. Since there was hardly any difference in leaf spotting between previously spotted and unspotted leaves these data have been combined in Fig. 1 and 2.

The total spotted area per leaf was not influenced by growth substance treatment for the first $24 \mathrm{~h}$. After $48 \mathrm{~h} \mathrm{GA}_{4+7}$ and $\mathrm{GA}_{3}$ treated leaves started to show a slightly larger spotted area than control leaves and after $72 \mathrm{~h}$ all concentrations of $\mathrm{GA}_{4+7}$ and $\mathrm{GA}_{3}$ markedly increased the magnitude of spot development over all other treatments (Fig. 2). $\mathrm{GA}_{3}$ was the least severe of the 2 gibberellin treatments in influencing leaf spot. IAA, PBA and ABA had no influence on the size of the spotted area. 
Table 1. The effect of $\mathrm{GA}_{4+7}$ and PBA alone and in combination at various concentrations on the spotting of detached 'Golden Delicious' apple leaves after $72 \mathrm{~h} .{ }^{1}$

\begin{tabular}{rrll}
\hline $\mathrm{GA}_{4+7}(\mathrm{mg} /$ litre $)$ & PBA & $\begin{array}{l}\text { Leaves showing } \\
\text { spots }(\%)\end{array}$ & $\begin{array}{l}\text { Spotted area } \\
\text { per leaf }\left(\mathrm{cm}^{2}\right)\end{array}$ \\
0 & & & \\
0 & 0 & 20 & 0.2 \\
0 & 1 & 10 & 0.2 \\
0 & 10 & 10 & 0.3 \\
1 & 100 & 30 & 0.6 \\
1 & 0 & 40 & 1.0 \\
1 & 1 & 30 & 1.1 \\
1 & 10 & 60 & 1.7 \\
10 & 100 & 60 & 1.9 \\
10 & 0 & 50 & 2.8 \\
10 & 1 & 60 & 2.2 \\
10 & 10 & 80 & 4.2 \\
100 & 100 & 90 & 6.5 \\
100 & 0 & 90 & 12.4 \\
100 & 1 & 80 & 15.6 \\
100 & 10 & 100 & 20.8 \\
\hline
\end{tabular}

1 Mean of 10 leaves per treatment.

The number of spots per leaf was found to be an unreliable index of leaf spot severity since spots tended to coalesce in advanced stages of the disorder.

Leaves of the cultivar 'Jonathan' detached from adjacent trees did not developed leaf spotting when treated with gibberellins as described above, thus substantiating the cultivar specificity of leaf spot.

Experiment 2. PBA alone had no influence on the percentage leaves developing spots at the 3 concentrations tested (Table 1). $\mathrm{GA}_{4+7}$ alone at $1 \mathrm{mg} /$ litre or together with PBA at $1 \mathrm{mg} /$ litre did not influence leaf spotting but when the PBA concentration of the solution was increased to 10 and $100 \mathrm{mg} /$ litre the severity of the disorder increased somewhat.

$\mathrm{GA}_{4+7}$ alone at $10 \mathrm{mg} /$ litre slightly provoked leaf spot and was increased further at that concentration by the addition of PBA at 10 and $100 \mathrm{mg} /$ litre to the solution. At the latter combination some synergism existed in the number of leaves developing spots and a highly synergistic effect was found in the total spotted area per leaf.

$\mathrm{GA}_{4+7}$ alone at $100 \mathrm{mg} /$ litre markedly increased the severity of leaf spot over control leaves. This effect was greatly magnified by the addition of PBA at 10 and $100 \mathrm{mg} /$ litre to the solutions. Application of $\mathrm{GA}_{4+7}$ and PBA at high concentrations consistently gave a synergistic effect. This effect increased the spotted area per leaf from 1.4 to 2.5 times that expected from an additive effect. The magnitude of the synergism increased as the concentration of the hormones increased. 


\section{Discussion}

It was previously reported that the incidence of physiological leaf spot could be hastened and intensified in leaves of intact 'Golden Delicious' apple trees by foliar applications of $\mathrm{GA}_{4+7}$ (Kender \& Jonkers, 1975). Although young expanding leaves synthesize considerable amounts of auxins and gibberellins, mature leaves depend upon the import of these hormones. Our premise in repeating similar experiments with detached leaves was that if gibberellins induce physiological leaf spot detached (non-importing) control leaves should produce no spots while spots should appear on GA-treated leaves. We found, as with intact leaves, that spots could be readily produced by culturing leaves in $\mathrm{GA}_{3}$ or $\mathrm{GA}_{4+7}$ solutions. However, 20 to $30 \%$ of the control leaves also produced spots and we were unable to demonstrate the causal effect of leaf spot. Although caution was exercised in sampling leaves many nodes from the nearest spot, it is possible that some of the test leaves may have been predisposed to leaf spotting prior to detachment. It is evident nevertheless, that both $\mathrm{GA}_{3}$ and $\mathrm{GA}_{4+7}$ at high concentrations triggered very rapid development of leaf spot suggesting that leaf spot in 'Golden Delicious' apple leaves is influenced by rapid changes in hormone balance. On leaves of intact trees, ABA retarded but did not inhibit the development of leaf spot (Kender \& Jonkers, 1975). Such as response was not detected in detached leaves.

The synergistic effect of $\mathrm{GA}_{4+7}$ and PBA in increasing the severity of leaf spot of detached leaves was of interest since a similar observation was made when the same combination was applied to leaves of adjacent intact fruiting trees but not in young non-fruiting trees in the phytotron.

The use of detached apple leaves indicates that gibberellin promoted leaf spot is not necessarily related to rapid shoot growth but rather a localized phenomenon within the affected leaf.

It is concluded from these data and that from previous work on intact trees (Jonkers, 1973a; Kender \& Jonkers, 1975), that external conditions affording rapid synthesis of gibberellins promote physiological leaf spot in 'Golden Delicious' apple trees.

\section{References}

Jonkers, H., 1973a. Leaf spot and leaf drop of the apple cultivar 'Golden Delicious': a physiological disorder. Neth. J. agric. Sci. 21: 171-180.

Jonkers, H., 1973b. Review of leaf spot and leaf drop: a physiological disorder of the 'Golden Delicious' apple. Scientia Hort. 1: 231-237.

Kender, W. J. \& H. Jonkers, 1975. Hormonal regulation of physiological leaf spot and premature leaf abscission in 'Golden Delicious' apple trees. Scientia Hort. (in press). 